ఠ

RETRACTION

\title{
The influence of goal-directed fluid therapy on the prognosis of elderly patients with hypertension and gastric cancer surgery [Retraction]
}

Zeng K, Li YZ, Liang M, Gao YG, Cai HD, Lin CZ. The influence of goal-directed fluid therapy on the prognosis of elderly patients with hypertension and gastric cancer surgery. Drug Des Devel Ther. 2014;8:2113-2119.

This article has been retracted at the request of the Editorin-Chief of Drug Design, Development and Therapy. It was brought to the attention of the Editorial team that the study period dates and patient details had been incorrectly reported. Due to the extent of the inaccuracies, the scientific validity of the data, and hence the conclusions, are questionable.

\section{Publish your work in this journal}

Drug Design, Development and Therapy is an international, peerreviewed open-access journal that spans the spectrum of drug design and development through to clinical applications. Clinical outcomes, patient safety, and programs for the development and effective, safe, and sustained use of medicines are the features of the journal, which

\section{Dovepress}

has also been accepted for indexing on PubMed Central. The manuscript management system is completely online and includes a very quick and fair peer-review system, which is all easy to use. Visit http://www.dovepress.com/testimonials.php to read real quotes from published authors. 